\title{
Characteristics Of The Demographic Development Of Cis: A Case Study Of Uzbekistan
}

\author{
Abduramanov Xamid Xudaybergenovich, PhD Candidate \\ Tashkent State University of Economy, Faculty of Economy, \\ Republic of Uzbekistan
}

doi: 10.19044/esj.2016.v12n11p280 URL:http://dx.doi.org/10.19044/esj.2016.v12n11p280

\begin{abstract}
This article gives a specified place of population of the Republic of Uzbekistan among the CIS countries. A dynamics of the population of the Republic of Uzbekistan for 1991-2015 was obtained. Also, an analysis of the structure of the population according to number, age and distribution was carried out. The determined factors affecting the age structure of the population was also ascertained. Demographic pressure factor was calculated. A long-term demographic forecast of Uzbekistan was carried out for the period until 2030. The territory of the Republic of Uzbekistan and the CIS countries were divided into groups according to the level of ageing population. They developed scientifically based proposals and recommendations towards improving the welfare of elderly people on the basis of the current demographic situation in Republic of Uzbekistan.
\end{abstract}

Keywords: Population, ageing of population, demographic processes, population forecast, population pressure

\section{Introduction}

Any political, economic, and social processes are connected with demographic characteristics. Hence, it has a significant influence on the life of the society in all countries. Fluctuation in birth rate is directly reflected in government expenditures on social services, employment in labor market, and the formation of health care and education system after a specific period of time.

CIS countries are part of the area of two demographic poles of Eurasia - negative European macro pole and positive Asian macro pole. In its turn, European CIS countries together with countries of Eastern Europe form a negative mezzo pole. Therefore, this is characterized by the following qualitative and quantitative parameters: 1) share in the world population $4.7 \%$; 2 ) the fourth stage of first "demographic transition" and the beginning 
of the second; 3) rate of annual decline of the population - $0.5 \%$; and 4) natural population decline - 3 \% (Antipova, E., Fakeyeva, L).

For the years of independence, a peculiar demographic situation in the Republic of Uzbekistan has been created. Therefore, it can be seen in terms of reducing the rate of population growth, decreasing the birth rate, increasing share of elderly people in the population age structure, reducing youth volume, and at the same time, increasing the number of middle-aged population and strengthening the urbanization process.

Since 2000 in Uzbekistan, the process of ageing of population began from the bottom due to sharp reduction in birth rate in transition period to new economic conditions. Consequently, this joins the population which was born in the period of "demographic reinforcement” after World War II to the group of elderly people.

However, demographic forecasts show that the demographic processes in Uzbekistan are intensively changing in perspective. Also, the rate of ageing of population is faster in the Republic relatively. Taking this fact into account, the analysis of the characteristics of demographic development of the Republic of Uzbekistan and development of relevant scientific and practical suggestions and recommendations are the most relevant issues today.

\section{Literature Review}

The concept of demographic development were studied by various scientists such as Pigou, A (1985), Survey, A (1977), Malthus, Th (1992), Smith, A., Keynes, J., Rosset, Ch and other foreign scholars. In CIS countries, scientific researches in the sphere of demographic development features were carried by scientists such as Rybakowsi, J (2000), Medkov, M., Rimashevskaya, N et al. (2004), Kvasha, A (1985), Iontsev, A., Kalinyuk, O (1975), Urlanis, S., Ermakov, S., Pirozhkov (1976), Korakhonov, M., Mullazhonov, I (1983), Kamilova, F., Ota-Mirzaev, O., Maksakov, L., Saliev, S et al. (2005), Kayumov, A., Buriyeva, M (1997) and others.

Thus, the analysis of the scientific works of these researchers have shown that research on studying the issues of ageing of population in the Republic of Uzbekistan was poorly conducted. Hence, issues of ageing of population require deep scientific research.

The Republic of Uzbekistan is a country which has a high demographic potential today. $0.42 \%$ (7.2 billion people) of the world's population is the share of Uzbekistan.

Subsequently, Uzbekistan among the CIS countries has been included in a number of republics in which the population is growing at the highest rate (Table 1 ). 
Table 1. Dynamics of the number of population in Central Independent States countries, mil.person (beginning of the year)

\begin{tabular}{|c|c|c|c|c|c|c|c|c|c|}
\hline \multirow[t]{2}{*}{ Countries } & \multicolumn{7}{|c|}{ Years } & \multicolumn{2}{|c|}{$\begin{array}{c}\text { Changes in } \\
2015 \\
\text { comparing } \\
\text { with } 1991 \\
\end{array}$} \\
\hline & 1991 & 1996 & 2001 & 2012 & 2013 & 2014 & 2015 &,+- & $\%$ \\
\hline CIS & 282,3 & 284,6 & 280,7 & 281 & 282 & 282 & 282 & $-0,3$ & 99.9 \\
\hline Armenia & 3,5 & 3,7 & 3,8 & 3,0 & 3,0 & 3,0 & 3,0 & $-0,5$ & 85.7 \\
\hline Belorussia & 10,2 & 10,2 & 10,0 & 9,5 & 9,5 & 9,5 & 9,5 & $-0,7$ & 93.1 \\
\hline Kyrgyzstan & 4,4 & 4,6 & 4,9 & 5,6 & 5,7 & 5,8 & 5,9 & 1,5 & 134.1 \\
\hline Kazakhstan & 16,8 & 15,6 & 14,8 & 16,7 & 16,9 & 17,2 & 17,4 & 0,6 & 103.5 \\
\hline Moldova & 4,3 & 4,3 & 4,2 & 3,6 & 3,6 & 3,6 & 3,6 & $-0,7$ & 83.7 \\
\hline Azerbaijan & 7,2 & 7,7 & 8,1 & 9,2 & 9,4 & 9,5 & 9,6 & 2,4 & 133.3 \\
\hline Russia & 148,5 & 147,9 & 144,8 & 143,1 & 143,3 & 143,7 & 146,3 & $-2,2$ & 98.5 \\
\hline Tajikistan & 5,3 & 5,9 & 6,2 & 7,8 & 8,0 & 8,2 & 8,4 & 3,1 & 158.5 \\
\hline Turkmenistan & 3,7 & 4,6 & 4,8 & 5,0 & 5,1 & 5,2 & 5,3 & 1,6 & 143.2 \\
\hline Ukraine & 52,0 & 51,3 & 49,0 & 45,5 & 45,4 & 45,2 & 42,8 & $-9,2$ & 82.3 \\
\hline Uzbekistan & 20,7 & 23,0 & 24,9 & 29,6 & 30,0 & 30,5 & 31,0 & 10,3 & 150.5 \\
\hline
\end{tabular}

Source: www.prb.org. World Population Data Sheet - 1991-2014, Population and social indicators of CIS countries and separated countries of the world 2011-2014, International

State Statistics Committee of CIS (2015). Moscow, p.7.

As shown in Table 1, in 1991-2015, the population number in countries such as Tajikistan (58.5\%), Uzbekistan (50.5\%), Turkmenistan (43.2\%), Kyrgyzstan (34.1\%), Azerbaijan (33.3\%) and Kazakhstan (3.5\%), has grown significantly. In all other CIS countries, they experienced depopulation process (reduction of population). Among the countries that are experiencing depopulation process, it was only in Russia that a growth of population number has been observed since 2012. Thus, this means in Russia, the population number has increased in 2015 compared to 2012.

Uzbekistan among the CIS countries occupies the third place according to the volume of the population number after Russia (51.6\%) and Ukraine (15.1\%). Hence, this makes up $10.9 \%$ of the total population number (CIS Interstate Statistical Committee, 2015).

According to the data of Committee on Statistics of the Republic of Uzbekistan, the population number has increased to 10.4 million people in 1991-2015. Thus, this accounts for 31,022,500 people in January 1, 2015 (Table 2). 
Table 2. Number of constant population of Republic of Uzbekistan and the changes of the process of the middle increase level (beginning of the year)

\begin{tabular}{|c|c|c|c|c|c|c|}
\hline \multirow{2}{*}{ Areas } & \multicolumn{3}{|c|}{$\begin{array}{c}\text { Constant number of population, } \\
\text { thousand person }\end{array}$} & \multicolumn{3}{|c|}{$\begin{array}{c}\text { Degree of yearly mid. increase } \\
\text { number, \% }\end{array}$} \\
\hline & 1991 & 2001 & 2015 & 1991 & 2001 & 2015 \\
\hline Uzbekistan Republic & 20607,7 & 24813,1 & 31022,5 & 2,4 & 1,3 & 1,7 \\
\hline \multicolumn{7}{|l|}{ Such as: } \\
\hline $\begin{array}{c}\text { Karakalpakistan } \\
\text { Republic }\end{array}$ & 1270,6 & 1527,0 & 1763,1 & 2,9 & 1,6 & 1,5 \\
\hline Andijan & 1789,0 & 2216,5 & 2857,3 & 2,4 & 1,4 & 1,8 \\
\hline Bukhara & 1195,1 & 1437,7 & 1785,4 & 2,7 & 1,3 & 1,7 \\
\hline Jizzakh & 792,2 & 991,5 & 1250,1 & 3,4 & 1,7 & 1,9 \\
\hline Kashkadarya & 1694,4 & 2212,5 & 2958,9 & 3,5 & 2,1 & 2,2 \\
\hline Navai & 682,0 & 791,1 & 913,2 & 2,5 & 1,0 & 1,3 \\
\hline Namangan & 1551,8 & 1953,2 & 2554,2 & 3,0 & 1,5 & 2,0 \\
\hline Samarkand & 2200,9 & 2710,0 & 3514,8 & 2,5 & 1,5 & 2,0 \\
\hline Surkhandarya & 1332,0 & 1770,4 & 2358,3 & 3,7 & 1,9 & 2,2 \\
\hline Syrdarya & 559,1 & 649,9 & 777,1 & 1,1 & 1,2 & 1,7 \\
\hline Tashkent & 2129,8 & 2370,2 & 2758,3 & 1,2 & 0,9 & 1,2 \\
\hline Fergana & 2214,6 & 2697,5 & 3444,9 & 2,5 & 1,2 & 1,7 \\
\hline Khorasm & 1066,0 & 1347,7 & 1715,6 & 3,0 & 1,8 & 1,9 \\
\hline Tashkent city & 2130,2 & 2137,9 & 2371,3 & 0,6 & $-0,2$ & 0,8 \\
\hline
\end{tabular}

Source: www.stat.uz. The information of State Statistics of Republic of Uzbekistan

As shown in Table 2, for the past 24 years, the population number of the Republic of Uzbekistan has increased to 50.5\%. During this period, the rate of population growth was higher than the average indicator of the republic in Andijan region (59.7\%), Jizzakh region (57.8\%), Kashkadarya region (74.6\%), Namangan region (64.6\%), Samarkand region (59.7\%), Surkhandarya region (77\%), Fergana region (55.5\%), and Khorezm region (60.9\%). Thus, in other regions, it was lower.

The analysis shows that the rate of the annual growth of the population in Uzbekistan was $2.4 \%$ in $1991,1.3 \%$ in 2001 , and $1.7 \%$ in 2015. It is possible to see that until 2001, the annual growth rate of the population has dramatically decreased in the republic. This situation is characterized by a decrease in birth rate. If total fertility rate in the Republic of Uzbekistan was $34.5 \%$ in 1991, this figure was $21.2 \%$ in 2010, and 23.3 $\%$ in 2014.

Therefore, reducing the birth rate in the Republic of Uzbekistan for the years of independence is characterized by the following factors: family;

- planning a family based on the economic capabilities of each

- changing the age of getting married;

- changing policy of the population health care. This means to direct 
people to give birth and bring up a healthy baby at the expense of increasing interval between births, encouraging women to give birth at optimum age of between 20-30 years, further expansion of using contraceptives, including free drugs;

- wide spread use of contraceptives to prevent unwanted pregnancies;

- changing reproductive attitudes of women by giving birth to small numbers of children, due to increasing financial liability of the families. It is simultaneously connected with an important role of women in the formation of financial resources of family budget;

- influence of trends on fertility reduction which is happening around the world.

Analysis of average annual rate of population growth in the Republic of Uzbekistan has shown that this indicator is at its lowest level in Tashkent city and Tashkent region. This situation is characterized by the following factors: high level of economic development and urbanization; low birth rates relatively to other territories; high mortality rates relatively to other territories; and higher share of elderly people in the population structure.

Each demographic “innovation” in Uzbekistan arises in Tashkent city and Tashkent region and extends in two directions, i.e. to south-west and east. It should be noted that changes in birth rate and natural increase are recorded after some time especially in southern areas of the republic - in Kashkadarya and Surkhandarya regions. In other words, southern regions reach current demographic situation in Tashkent region after some time (Saliyev et al., 2005).

Therefore, especially in these regions (Kashkadarya and Surkhandarya), the rate of the average annual growth of the total population is higher than in other areas. This means that in 1991, the rate of the annual growth of the population was $3.7 \%$ in Surkhandarya region and 3.5\% in Kashkadarya region. In 2015, average annual rate of population growth in these two regions was the same and equal to $2.2 \%$. In addition, the analysis show that $50 \%$ of the population of the republic (2015) is the share of 5 regions, i.e. Samarkand (11.3\%), Fergana (11.0\%), Kashkadarya (9.5\%), Andijan (9.2\%), and Tashkent (8.9\%) regions. Settlements of the Republic of Uzbekistan are divided into urban settlements (towns, urban villages) and rural settlements (villages, auls). Furthermore, $51 \%$ of the population of the republic lives in cities, while the rest $49 \%$ lives in rural areas (Table 3). 
Table 3. Regional settlement of population in Republic of Uzbekistan (beginning of the year)

\begin{tabular}{|c|c|c|c|c|c|c|}
\hline & \multicolumn{3}{|c|}{ Number of population in the city } & \multicolumn{3}{c|}{ Number of population in the village } \\
\cline { 2 - 7 } Years & $\begin{array}{c}\text { Thous. } \\
\text { Person }\end{array}$ & $\begin{array}{c}\text { Yearly mid. } \\
\text { Increase } \\
\text { rate } \\
\%\end{array}$ & $\begin{array}{c}\text { Influence in } \\
\text { the total } \\
\text { structure of } \\
\text { population, } \\
\%\end{array}$ & $\begin{array}{c}\text { Thous. } \\
\text { person }\end{array}$ & $\begin{array}{c}\text { Yearly } \\
\text { mid. } \\
\text { Increase } \\
\text { rate \% }\end{array}$ & $\begin{array}{c}\text { Influence in } \\
\text { the total } \\
\text { structure of } \\
\text { population, } \\
\%\end{array}$ \\
\hline 1991 & 8304,9 & 1.7 & 40.3 & 12302,8 & 2.9 & 59.7 \\
\hline 1995 & 8671,0 & 1.1 & 38.6 & 13790,6 & 2.3 & 61.4 \\
\hline 2000 & 9165,6 & 0.7 & 37.4 & 15322,2 & 1.5 & 62.6 \\
\hline 2001 & 9225,3 & 0.6 & 37.2 & 15587,8 & 1.7 & 62.8 \\
\hline 2005 & 9441,9 & 0.6 & 36.3 & 16579,4 & 1.5 & 63.7 \\
\hline 2006 & 9495,1 & 0.6 & 36.1 & 16817,6 & 1.4 & 63.9 \\
\hline 2007 & 9584,6 & 0.9 & 35.9 & 17079,2 & 1.5 & 64.1 \\
\hline 2008 & 9698,2 & 1.1 & 35.8 & 17374 & 1.7 & 64.2 \\
\hline 2009 & 14236 & 46.8 & 51.7 & 13297,4 & -23.5 & 48.3 \\
\hline 2010 & 14425,9 & 1.3 & 51.5 & 13575,5 & 2.1 & 48.5 \\
\hline 2011 & 14897,4 & 3.2 & 51.2 & 14225,9 & 4.8 & 48.8 \\
\hline 2012 & 15143,2 & 1.6 & 51.2 & 14412,1 & 1.3 & 48.8 \\
\hline 2013 & 15370,1 & 1.5 & 51.2 & 14623,4 & 1.4 & 48.8 \\
\hline 2014 & 15555,2 & 1.2 & 51.0 & 14937,6 & 2.1 & 49.0 \\
\hline 2015 & 15748,0 & 1.2 & 50.8 & 15274,5 & 2.2 & 49.2 \\
\hline
\end{tabular}

Source: Demographic yearbook of Uzbekistan 1991-2003, State Statistics Committee of the Republic of Uzbekistan (2014). Tashkent, Population of Uzbekistan (2015). Statistic collection. Tashkent, p.11.

As shown in Table 3, the number of urban population increased by $89.6 \%$ and the number of rural population increased by $24.1 \%$ in 2015 in comparison to 1991. The analyses show that the rate of average annual growth in the number of rural population is higher in comparison with the urban population. Thus, this is due to a high birth rate in rural areas. For example, if general fertility rate in rural areas was $39.8 \%$ in 1991, then in 2015, this figure is equal to $25.9 \%$. This rate was $26.7 \%$ and $20.8 \%$, respectively in urban areas.

It should be noted that the number of urban population has grown by 46.8\% in 2009 in comparison with 2008, while the number of rural population decreased by $23.5 \%$ on the contrary. This situation is characterized by the fact that 965 rural settlements of the republic were granted the status of urban settlements according to the Decree of the Cabinet of Ministers of the Republic of Uzbekistan №68 dated March 13, 2009 "on additional measures to improve administrative and territorial structure of settlements of the Republic of Uzbekistan".

That is, according to the above mentioned decree, the following villages were turned into urban settlements in the Republic of 
Karakalpakstan - 11; Andijan region - 79; Bukhara region - 59; Jizzakh region - 33; Kashkadarya region - 117; Navoi region - 29; Namangan region - 108; Samarkand area - 75; Surkhandarya region - 106; Syrdarya region - 15; Tashkent region - 78; Ferghana region - 198; and Khorezm region -50 .

In 2011, the rate of average annual population growth in the republic reached its highest level (4.0\%). Over the years, the urban population number grew by $3.2 \%$ and the number of rural population by $4.8 \%$. This situation is related to the detection of mechanical increase by 642,500 people in selective statistical observations of population number. Subsequently, it was conducted covering $10 \%$ of the population in each town and region of the republic on the basis of the Decree of Cabinet of Ministers of the Republic of Uzbekistan №71 on March 14, 2011 "on measures to preparation and conduction of selective statistical observation of population" (Decree of the Cabinet of Ministers of the Republic of Uzbekistan №71, March 14, 2011).

The population of the Republic of Uzbekistan is usually characterized by tendency of mechanical reduction. In particular, number of population of the republic decreased mechanically by 66.6 thousand people in 2000 and 38.5 thousand people in 2015. According to statistical data, major part of people (92.5\%) who left for other countries from Uzbekistan are people who go to Russia (43.6\%) and the Republic of Kazakhstan (48.9\%).

Today (2015), the level of urbanization in the Republic of Uzbekistan is $51.0 \%$. Uzbekistan occupies first place on the level of urbanization in the CIS than other republics such as Tajikistan (27\%), Kyrgyzstan (36\%), and Moldova (42\%) (World population data sheet, 2015).

Basically, the labor legislation population of the Republic of Uzbekistan is divided into 3 groups on labor capacity: below working age (015 years), working age (women 16-54, men 16-59), and above working age (women 55 and over, men 60 and over) (Abdurakhmanov \& Imomov, 2008). If we analyze the amount of groups on the basis of the working population in the Republic of Uzbekistan, then we can see that the higher share of the population is under working age (Table 4). 
Table 4. The changes of demographic pressure to population at the age of working people in Republic of Uzbekistan (beginning of the year)

\begin{tabular}{|c|c|c|c|c|c|c|c|}
\hline \multirow{2}{*}{ Years } & \multicolumn{2}{|c|}{$\begin{array}{l}\text { Population at the } \\
\text { age of the ability to } \\
\text { work }\end{array}$} & \multicolumn{2}{|c|}{$\begin{array}{l}\text { Population at the } \\
\text { age of the ability } \\
\text { to work }\end{array}$} & \multicolumn{2}{|c|}{$\begin{array}{l}\text { Upper people at the } \\
\text { age of the ability to } \\
\text { work }\end{array}$} & \multirow{2}{*}{$\begin{array}{l}\text { Demographic } \\
\text { pressure } \\
\text { (number of } \\
\text { population at the } \\
\text { age of disability } \\
\text { to work which } \\
\text { was equal in } \\
\text { each 1000), } \\
\text { person }\end{array}$} \\
\hline & $\begin{array}{l}\text { Thosand } \\
\text { person }\end{array}$ & $\%$ & $\begin{array}{l}\text { Thosan } \\
\text { d } \\
\text { person }\end{array}$ & $\%$ & $\begin{array}{l}\text { Thosand } \\
\text { person }\end{array}$ & $\%$ & \\
\hline 1991 & 9117,6 & 43.2 & 10352,8 & 49.1 & 1635,7 & 7.7 & 1038,7 \\
\hline 1995 & 9797,9 & 42.8 & 11357,3 & 49.6 & 1751,2 & 7.6 & 1016,9 \\
\hline 2000 & 9864,4 & 39.8 & 13142,9 & 53.0 & 1805,7 & 7.3 & 887,9 \\
\hline 2005 & 9217,0 & 35.0 & 15241,3 & 57.9 & 1854,2 & 7.0 & 726,4 \\
\hline 2010 & 8982,9 & 32.1 & 16953,6 & 60.5 & 2064,9 & 7.4 & 651,6 \\
\hline 2014 & 9116,6 & 29.9 & 18814,0 & 61.7 & 2562,2 & 8.4 & 620,8 \\
\hline 2015 & 9275,8 & 29.9 & 19047,8 & 61.4 & 2698,9 & 8.7 & 628,7 \\
\hline $\begin{array}{c}\text { The } \\
\text { change } \\
\text { s in } \\
2015 \\
\text { accordi } \\
\text { ng to } \\
1991 \text {, } \\
\%\end{array}$ & 101.7 & - & 183.9 & - & 165.0 & - & - \\
\hline
\end{tabular}

Source: Table done according to the information of State Statistics of Republic of Uzbekistan.

As shown in Table 4, in the course of 1991-2015, there was an increased population number under working age in the Republic of Uzbekistan by $1.7 \%$. The analysis of dynamics of the number of this group of population shows that it increased by $82 \%$ in 1991-2000, and decreased by $9.0 \%$ in $2000-2010$. However, it grew to $3.3 \%$ in $2010-2015$. In the period up to 2010, reduction in population number under working age provided a decrease in birth rate. Since 2010, there was an increase in the number of population birth rate in the country.

In the years of independence and its first years, there was a regular increase in the number of able-bodied population from 1991 to 2014. Nevertheless, this was because there were high rates of birth in Uzbekistan. In addition, for this period, their number had reached 18814.0 thousand from 10352.8 thousand people or have increased by $83.9 \%$.

Today, population shift to the number of people above working age. Therefore, the high birth rate after World War II provides the growth with high rates of this group in the population structure of the Republic of Uzbekistan. That is, the number of population of above working age 
increased by $65.0 \%$ in 2014 as compared to 1991. Therefore, this results to $8.7 \%$ of the population.

Increasing the number of people above working age (elderly) in the population structure is also connected with the continuation of life expectancy at birth. If in the Republic of Uzbekistan, continuation of life expectancy expected at birth was 69.3 (National Economy of Uzbekistan in 1993, 1994 ) in 1991, then it reached 73.5 in 2014, and has increased to 4.2 years for 24 years.

It should be noted that disabled population makes its demographic pressure upon able-bodied. According to calculations, if the number of disabled people per 1.000 people of working age was 1038.7 people in 1991 , then this figure had been equal to 620.8 people by 2014. In other words, there was 1 able-bodied person to 1 disabled person in 1991. Also, there are 0.6 disabled persons in 2014. This is certainly a positive result. Demographic situation which occurred in Uzbekistan requires increase in the effectiveness of using labor resources.

Changes in age structure of population of the Republic of Uzbekistan are calculated differently (Table 5).

Table 5. Age structure of constant population in the Republic of Uzbekistan, \% (for the beginning of the year)

\begin{tabular}{|l|l|l|l|l|l|l|}
\hline \multirow{2}{*}{ Areas } & \multicolumn{3}{|l|}{$\begin{array}{l}\text { Under the age of } \\
\text { ability to work }\end{array}$} & \multicolumn{2}{l}{$\begin{array}{l}\text { Age of ability to } \\
\text { work* }\end{array}$} & \multicolumn{2}{l}{$\begin{array}{l}\text { Upper age of ability } \\
\text { to work }\end{array}$} \\
\cline { 2 - 7 } & 1991 & 2015 & 1991 & 2015 & 1991 & 2015 \\
\hline Uzbekistan Republic & 43,2 & 29,9 & 49,1 & 61,4 & 7,7 & 8,7 \\
\hline $\begin{array}{l}\text { Karakalpakistan } \\
\text { Republik }\end{array}$ & 46,6 & 31,4 & 47,1 & 61,1 & 6,3 & 7,5 \\
\hline regions: & & & & & & \\
\hline Andijan & 42,6 & 29,6 & 50,0 & 61,9 & 7,3 & 8,5 \\
\hline Bukhara & 43,2 & 28,3 & 50,1 & 62,6 & 6,7 & 9,1 \\
\hline Jizzakh & 46,6 & 31,6 & 46,8 & 60,3 & 6,6 & 8,1 \\
\hline Kashkadarya & 48,5 & 32,3 & 45,0 & 60,5 & 6,5 & 7,2 \\
\hline Navai & 43,1 & 28,7 & 50,0 & 62,7 & 6,9 & 8,6 \\
\hline Namangan & 44,6 & 29,8 & 48,2 & 62,3 & 7,2 & 7,9 \\
\hline Samarkand & 45,7 & 31,5 & 46,8 & 60,4 & 7,5 & 8,1 \\
\hline Surkhandarya & 48,5 & 32,2 & 44,9 & 60,8 & 6,7 & 7,0 \\
\hline Syrdarya & 46,5 & 30,9 & 47,1 & 62,1 & 6,4 & 7,0 \\
\hline Tashkent & 39,9 & 28,2 & 50,9 & 61,6 & 9,1 & 10,2 \\
\hline Fergana & 42,2 & 28,9 & 49,7 & 62,1 & 8,2 & 9,0 \\
\hline Khorasm & 46,5 & 31,2 & 46,7 & 61,3 & 6,8 & 7,5 \\
\hline Tashkent city & 30,8 & 25,0 & 57,5 & 60,7 & 11,7 & 14,3 \\
\hline
\end{tabular}

Source: Table done according to the information of State Statistics of Uzbekistan Republic. * men age of 16-59 лет, women age of 16-54.

As shown in Table 5, the percentage of population below working age in all territories of the Republic of Uzbekistan has sharply reduced. 
However, population coverage below working age is slightly higher in Kashkadarya and Surkhandarya regions, where the birth rate is higher than in other areas of the country.

For the years of independence in all areas of the republic, there is a dramatically increased percentage of working age population. Thus, this comprises $60 \%$ of the population. The highest rates of this group of population have been observed in Navoi (62.7\%), Bukhara (62.6\%), and in Namangan (62.3\%) regions.

For analyzed period, there also rose the percentage of people of working age in the population structure of territories. It should be noted that the percentage of people above working age is higher in Tashkent city (14.3\%), Tashkent (10.2\%), Bukhara (9.1\%), and Fergana (9.0\%) regions. Also, the lowest rates have been observed in Syrdarya (7.0\%), Surkhandarya (7.0\%), and Kashkadarya (7.0\%) regions.

Analysis of current trends in demographic processes occurring in the republic shows that there is a decrease in the amount of people under working age in the age structure of population. Nevertheless, this is contrary to increase proportion of working age and people who are older. In turn, this requires implementation of peculiar changes in the directions of the social and economic development of the country, providing jobs for the workingage population, and the development of the projects and programs of social protection of the elderly in the future.

Implementation of these measures is related to the definition of the prospects of the demographic development of the country. Taking this fact into account, there is a long-term demographic forecast of the Republic of Uzbekistan using the method of "advancing age" for the period up to 2030 (Table 6).

Table 6. Number of population of Republic Uzbekistan and prognosis structure

\begin{tabular}{|c|c|c|c|c|c|}
\hline \multirow[b]{2}{*}{ Indicators } & \multirow[b]{2}{*}{ Measure unit } & \multicolumn{3}{|c|}{ Years } & \multirow{2}{*}{$\begin{array}{c}\text { The changes in } \\
2030 \text { according to } \\
2020, \%\end{array}$} \\
\hline & & 2020 & 2025 & 2030 & \\
\hline Total population & $\begin{array}{c}\text { Thousand } \\
\text { person }\end{array}$ & 33259,7 & 34931,8 & 36497,4 & 109.7 \\
\hline \multicolumn{6}{|l|}{ From: } \\
\hline \multirow{2}{*}{$\begin{array}{l}\text { The number of the age of } \\
\text { ability to work population }\end{array}$} & $\begin{array}{c}\text { Thousand } \\
\text { person }\end{array}$ & 9379,2 & 9396,6 & 9233,8 & 98.4 \\
\hline & $\%$ & 28.2 & 26.9 & 25.3 & - \\
\hline \multirow{2}{*}{$\begin{array}{l}\text { The number of ability to work } \\
\text { population }\end{array}$} & $\begin{array}{l}\text { Thousand } \\
\text { person }\end{array}$ & 20321,8 & 21204,3 & 22190,5 & 109.2 \\
\hline & $\%$ & 61.1 & 60.7 & 60.8 & - \\
\hline \multirow{2}{*}{$\begin{array}{l}\text { The number of upper age } \\
\text { ability to work population }\end{array}$} & $\begin{array}{l}\text { Thousand } \\
\text { person }\end{array}$ & 3558,7 & 4331,5 & 5073,1 & 142.5 \\
\hline & $\%$ & 10.7 & 12.4 & 13.9 & - \\
\hline
\end{tabular}

Source: Structured according to the reports by author. 
As revealed in Table 6, for expected period, there is a regular increase in the population number in the Republic of Uzbekistan. Based on observation, it would attain an achievement of up to 36497.4 thousand people by 2030. For this period, there has been a decrease in the number of population under working age in the structure of the population by $1.6 \%$. Thus, the proportion of the population structure was to $25.3 \%$ in 2030 from 28.2\% in comparison with 2020. This situation is characterized by decrease in the birth rate in Uzbekistan over forecast period. It is observed that total fertility rate will be $19.0 \%$ in the country in 2020, $17.6 \%$ in 2025 , and 15.0 $\%$ in 2030.

Over forecast period, the population number of working age increased by $9.2 \%$. As a result of transition of population to the number of elderly people, the birth of which was occurred in the period of increased birth (1960-1970), there is a high rate of growth of the number of people above working age compared to other age groups. It is expected that the share of people over working age in the population structure will result to $10.7 \%$ in $2020,12.4 \%$ in 2025 , and $13.9 \%$ in 2030 .

There is a certain difference in the distribution of able-bodied population between urban and rural areas. That is, the proportion of people over working age in urban areas is higher in comparison with rural areas. This trend continues in the forecast period. As a result, the proportion of people over working age in the structure of the population is $15.8 \%$ in 2030 in urban areas and $12.0 \%$ in rural areas.

As a result of increasing the number of the elderly people, an increase in mortality rate in the Republic of Uzbekistan was observed. Total death rate in the country will be $5.3 \%$ in 2020, 5.9\% in 2025, and 6.6\% in 2030 .

UN demographers developed three-stage scale to assess the level of demographic ageing. These scale are: if the proportion of people aged 65 and over in the structure of the population less than $4 \%$ is a young population; if from 4 to $7 \%$ are on the threshold of demographic ageing; and if more than $7 \%$ is the elderly population (Demographic Encyclopedic Dictionary, 1985).

Furthermore, if we divide the CIS countries by this classification, we can see the following:

- population of Ukraine (15\%), Belarus (14\%), Russia (13\%), Armenia (11\%), Moldova (10\%), and Kazakhstan (7\%) is the elderly population; - population of Azerbaijan (6\%) is on the verge of demographic ageing;

- population of the Republic of Uzbekistan (4\%), the Republic of Turkmenistan (4\%), the Kyrgyz Republic (4\%), and the Republic of Tajikistan (3\%) are young population (World Population Data Sheet, 2015).

Demographic prognoses show that the expected proportion of people aged 65 and over in the population structure, will be $5.0 \%$ in 2020, 6.4\% in 
2025, and $7.5 \%$ in 2030. Consequently, by 2030, the population of Uzbekistan takes a worthy place in a number of countries with the elderly population.

As at present (2015) in the Republic of Uzbekistan, only the structure of the population of Tashkent city has the proportion of people aged 65 and over to be $7.1 \%$, the population is demographically elderly (Table 7).

Table 7. To divide into groups according to the aging degree of population of Uzbekistan Republic

\begin{tabular}{|c|c|c|c|}
\hline $\begin{array}{c}\text { Degree of aging } \\
\text { population }\end{array}$ & 2015 & 2025 & 2030 \\
\hline $\begin{array}{c}\text { Demographic } \\
\text { youth }\end{array}$ & $\begin{array}{c}\text { Karakalpakistan } \\
\text { Republic, Jizzakh, } \\
\text { Kashkadarya, } \\
\text { Samarkand, } \\
\text { Surkhandarya, } \\
\text { Syrdarya, and } \\
\text { Khorasm regions }\end{array}$ & $\begin{array}{c}\text { Karakalpakistan } \\
\text { Republic, Jizzakh, } \\
\text { Kashkadarya, } \\
\text { Surkhandarya, } \\
\text { Syrdarya, and } \\
\text { Khorasm regions }\end{array}$ & - \\
\hline $\begin{array}{c}\text { In the beginning } \\
\text { of demographic } \\
\text { aging }\end{array}$ & $\begin{array}{c}\text { Andijan, Bukhara, } \\
\text { Favai, Tashkent, and } \\
\text { Ferghana regions }\end{array}$ & $\begin{array}{c}\text { Bukhara, Samarkand, } \\
\text { and Namangan } \\
\text { regions }\end{array}$ & $\begin{array}{c}\text { Kepublic, Jizzakh, } \\
\text { Kashkadarya, } \\
\text { Surkhandarya, } \\
\text { Syrdarya, and } \\
\text { Khorasm regions }\end{array}$ \\
\hline $\begin{array}{c}\text { Demographic } \\
\text { aged }\end{array}$ & Tashkent city & $\begin{array}{c}\text { Andijan, Navai, } \\
\text { Tashkent and } \\
\text { Ferghana regions, and } \\
\text { Tashkent city }\end{array}$ & $\begin{array}{c}\text { Bukhara, Samarkand, } \\
\text { Namangan Andijan, } \\
\text { Navai, Tashkent and } \\
\text { Ferghana regions, and } \\
\text { Tashkent city }\end{array}$ \\
\hline
\end{tabular}

Source: The table structured according to the demographic prognosis of information by author.

As shown in table 7, the population of 5 territories in 2025 and 8 territories in 2030 is an elderly population. Increasing the number and proportion of the elderly population in the nearest future in the Republic of Uzbekistan requires special attention for this category of population.

A great attention to social support for the elderly is paid by the government of Uzbekistan. The Constitution of the Republic of Uzbekistan included articles such as "Minors, disabled and single elderly are under the protection of the state" and "Adult, able-bodied children are obliged to care for their parents" (Constitution of the Republic of Uzbekistan. 2003). According to a number of regulations of Cabinet of Ministers, funds "Makhalla" and "Nuroniy" are established. There, a system of providing social protection to the single elderly at home was introduced.

However, 2015 was declared "The Year of attention and care for the older generation" by the President of the Republic of Uzbekistan, Islam Karimov. 
The costs of implementing the measures of the State program of "The Year of attention and care for the older generation" are 2246.5 billion sum. It include the following: budgetary and extra-budgetary funds - 310.3 billion sum; funds of the executives and sponsors - 995.2 billion sum, commercial bank loans - 940.3 billion sum, and grants and funds from international organizations and financial institutions - 0,7 billion sum (Legislative Assembly of the Republic of Uzbekistan, 2015).

\section{Conclusion}

In our opinion, it is expedient to implement the following measures to further the improvement of the welfare of the elderly population living in the conditions of the current demographic situation formed in the Republic of Uzbekistan. These include:

- improving the financial condition of the off-budget Pension fund under the Ministry of Finance of the Republic of Uzbekistan. For this, they recommended a targeted draft on funds of the Pension Fund; reduction of preferential pension, equalization of the retirement age for men and women;

- further strengthening the level of targeted social support for the elderly by non-state funds. For this, the elderly who really need help and assistance should be provided with the necessary support, thereby maintaining continuous control. Also, the establishment of community councils with the elderly leading activities in makhallas; creation of center of the elderly with citizens self-government institutions; improvement of works to attract sponsor support to the single elderly; and the coordination of work in this area is recommended;

- creating Geriatric center under the Ministry of Health of the Republic of Uzbekistan and opening of the divisions of this center in all regions and cities of the republic, increasing types of medical care provided to this category of population. In our opinion, the main goal of Geriatric center is to create optimal conditions for improving the health of the elderly. Subsequently, their active participation in society life and long-term preservation of physical and psychological health is also considered as a major goal.

In our opinion, geriatric centers should implement the following set of measures to restore the health of the elderly: drawing up a list of the elderly living on each territory, treatment, and constant monitoring of chronic patients; organization of planned consultations for the elderly; continuous professional development of the district doctor and other specialists in geriatrics; conducting scientific and practical conferences on urgent issues devoted to this direction; introduction of prevention of ageing and modern geriatric method of treatment into practice, and latest achievements geropharmacology; 
- organizing "Small volume houses" in all areas of the country. In recent years, a topical issue of the organization of "House of small volume" designed for 5-10 people for the single elderly became urgent. On the basis of significant strengthening, there is a role and place of self-government bodies in solving the problems of single people.

As a result of the organization of such houses, firstly, single people remain in the regions and cities, where they previously lived themselves. Thus, they are accustomed to and will not need to adapt to new living conditions. Secondly, unlike conventional geriatric homes, where there reside an average of 200 people, there is a significant increase in the efficiency and quality of social protection organized on the account of the intensification of rendering individual services to single people in "small volume houses" (5-10 people);

- organization of "Sanatorium at home". Single elderly citizens have certain limitations while moving. If there is a "small movement" and subsequently there is significant difficulty of the possibility of trips to sanatorium for veterans of war and labor, they have the right to provide free medicines on the basis of the doctor's prescription in the treatment of the outpatient setting according to the current legislation.

Based on our view, the implementation of the above mentioned proposals and recommendations promotes the social and economic wellbeing of the elderly living in Uzbekistan.

\section{References:}

Abdurahmanov \& Imomov (2008). Positive usage of labour potential in Uzbekistan and its management. Monograph. T. Academy, p.42.

Buriyeva (1997). Demographics of family in Uzbekistan. Tashkent: University, p.117.

Constitution of the Republic of Uzbekistan (2003). T: Uzbekistan, pp.10-13. Demographic yearbook of Uzbekistan (2015). Tashkent, p. 57.

Demographic yearbook of Uzbekistan 1991-2003 (2004). Tashkent.

Demographic yearbook of Uzbekistan 2003 (2004). Tashkent, p.110.

Kvasha (1985). What is demographics?. M.: Miysl, p.126.

Kalinyuk (1975). Age structure of population of the USSR. Moscow: Statistics, p.112

Kamilov (1991). Demographic potential of Uzbekistan. Tashkent: Uzbekistan, p.143.

National economy of Uzbekistan in 1993 (1994). Publishing House: State Committee of forecasting of statistics, p. 73.

Legislative Assembly of the Republic of Uzbekistan (2015). № 8, art. 91. Malthus (1992). Experience about population law. Anthology of economic classics / Translated from Eng. Moscow. 
Mulladjanov (1983). Demographic development of Uzbek SSR. Tashkent: Uzbekistan, p.169.

National economy of Uzbekistan Republic in 1993 (1994). State prognoses of Statistics. Tashkent. p.73.

Pigu (1985). Economic theory of well-being.V.2, M: Progress, p.456

Pirozhkov (1976). Demographic processes and age structure of population. M: Statistics, p.135.

Population of Uzbekistan (2015). Statistic collection. Tashkent, p.11.

Population and social indicators of the CIS countries and individual countries 2011-2014 (2015). CIS Interstate Statistical Committee. Moscow, p.6.

Social development and living standards in Uzbekistan (2013). Statistic Collection. Tashkent, p.34.

Sovy (1977). General theory of population. V.1., M: Progress, p.502.

Rybakowsi (2000). Population policy: objectives, principles, priorities. Moscow: ISPR RAS, p.24.

Rimashevskaya et al. (2004). Population and globalization. M: Since, p.328. Soliev et al. (2005). Demography in village areas. Tashkent. UzNU, p.19.

State Statistics Committee of the Republic of Uzbekistan (2014). Tashkent

Social development and life style rate in Uzbekistan (2014). Statistic collection. Tashkent, p.41.

Social development and level of life in Uzbekistan (2015). Statistic collection. Tashkent. p.13.

The dictionary of Demographic encyclopedia (1985). Soviet encyclopedia. M. p.117.

The Constitutions of the Republic of Uzbekistan (2003). T. Uzbekistan, pp.10-13.

www.bsu.by. Antipova E., Fakeyeva L. Demographic area of the Commonwealth of Independent States: Structure and the main changes. www.lex.uz.Urbanization codex of Uzbekistan Republic (2002). Information book of Oliy Majlis of the Uzbekistan Republic, volume 4-5, article 63.

www.lex.uz. Attachment the decree 68 "The tasks about the administrative social structure of development of population branches of the Republic of Uzbekistan” on 13 March, 2009 of Cabinet Minesters of the Uzbaekistan Republic.

www.lex.uz. The decree number of 71 “About preparing the population for seperatly statistical analysis” on 14 March, 2011 of the Cabinet Ministry of Uzbekistan.

www.prb.org. World Population Data Sheet 2015.

www. Lex.uz. Attachment to the Decree № PO -2302 the State program of "About the year of honour elderly people" on 18 February, 2015 by the President of the Republic of Uzbekistan. (2015). Collection of law documents of the Republic of Uzbekistan. Volume 8, article 9. 